\title{
What are the traits of Phelipanche ramosa (L.) Pomel that contribute to the success of its biological cycle on its host Brassica napus L.?
}

\author{
Stéphanie Gibot-Leclerc ${ }^{\mathrm{a}, *}$, Georges Sallé $^{\mathrm{b}}$, Xavier Reboud $^{\mathrm{c}}$, Delphine Moreau $^{\mathrm{c}}$ \\ a AgroSup Dijon, UMR1347 Agroécologie, BP 86510, F-21000 Dijon, France \\ ${ }^{\mathrm{b}}$ Laboratoire de Parasitologie Végétale, UPMC Univ Paris 06, F-75005 Paris, France \\ ' INRA, UMR1347 Agroécologie, BP 86510, F-21000 Dijon, France
}

\section{A R T I C L E I N F O}

\section{Article history:}

Received 5 December 2011

Accepted 23 March 2012

\section{Keywords:}

Phelipanche ramosa (L.) Pomel = syn.

Orobanche ramosa $\mathrm{L}$.

Brassica napus L.

Parasitism

Biological cycle

Trophic relationships

Competition

\begin{abstract}
A B S T R A C T
In France, the fact that the holoparasitic plant Phelipanche ramosa has adapted to oilseed rape over the past two decades is deeply worrying, as it can cause over $80 \%$ yield losses. Its distribution area and the range of its host plants, whether they are cultivated plants or weeds, are expanding dramatically. As no natural regression of the infestation has been recorded so far, we undertook a detailed study of the different steps of the biological cycle of the $P$. ramosa/oilseed rape pathosystem to determine the adaptive traits that favour the parasite's success. We combined experimental approaches involving controlled conditions with in vitro and in pot co-cultivation on the one hand and a field trial on the other hand. These experiments allowed us to determine a 4-mm zone around host roots within which oilseed rape root exudates stimulate the germination of $P$. ramosa, the early action of host root exudates and the rapid fixation of the parasite on host roots. We also unveiled that $P$. ramosa was able to tune its biological cycle to that of oilseed rape. The important trophic relationships between the parasite and its host induced phenotypic (dwarfism, leaf chlorosis, silique abortion) as well as agronomical (90\% yield losses) consequences on oilseed rape. Our results can constitute a relevant basis for further experimental studies. The research perspectives they open will focus on key-processes of the host-parasite relationship, and more particularly on the trophic relationships that are set up as far as carbon assimilates and minerals such as nitrogen are concerned.
\end{abstract}

(C) 2012 Elsevier GmbH. All rights reserved.

\section{Introduction}

Among crop bioagressors, the Phelipanche and Orobanche genera are obligate parasites of dicotyledonous roots and are considered as one of the main biotic constraints on economically important crops. They are also known to be the cause of crop losses ranging from 5 to 100\% (Joel et al., 2007; Musselman, 1980; Parker and Riches, 1993; Press and Graves, 1995; Press and Phoenix, 2005; Schneeweiss, 2007). Phelipanche ramosa (L.) Pomel (Joel, 2009) is most devastating and has by far the widest range of hosts, among which Solanaceae, Brassicaceae and legumes are prominent (Buschmann et al., 2005; Haidar et al., 2003; Joel et al., 2007; Parker and Riches, 1993). In France, P. ramosa got remarkably adapted to oilseed rape, causing deeply worrying losses of about $80 \%$, but also to hemp and tobacco. So far the adaptation of P. ramosa to oilseed rape seems to have remained limited to the French territory. The distribution area

\footnotetext{
* Corresponding author at: AgroSup Dijon, UMR 1347 Agroécologie, Département Agronomie Agroéquipement Elevage Environnement, 26 Bd Dr Petitjean, BP 87999, 21079 Dijon Cedex, France. Tel.: +33 03807728 03; fax: +33 0380772551.

E-mail address: stephanie.gibot-leclerc@dijon.inra.fr (S. Gibot-Leclerc).
}

of the parasite and the range of its host plants appear to have dramatically expanded lately, with more than 70 weed species as new hosts (Boulet et al., 2007; Brault et al., 2007; Gibot-Leclerc et al., 2003, 2006, 2009).

The biological cycle of epirhizal parasites is usually composed of two distinct phases (Bouwmeester et al., 2003; Joel et al., 2007; Keyes et al., 2001; Parker and Riches, 1993; Rubiales, 2003; Sauerborn, 1991; Yoder, 2001). Underground, the first phase is initiated by seed germination and goes on with the fixation on host roots and the penetration into host tissues along with the development of an absorption system called a haustorium. Aboveground, the second phase starts with the emergence and then the growth of floral scapes and ends with flowering and fructification. In recent years several authors (Buschmann et al., 2005; Echevarría-Zomeño et al., 2006; Goldwasser et al., 2001; Haidar et al., 2003; Kogan, 1994; Lu et al., 2000; Pérez de Luque et al., 2004; Sallé et al., 2000) have insisted on the need to increase our knowledge about parasitic plant biology in order to make it easier to develop suitable protocols for an efficient control. The knowledge acquired about broomrape so far deals with the biology of the main broomrape/host pathosystems, i.e. Orobanche cernua/sunflower, 0 . crenata/faba bean, 0 . cumana/sunflower, Phelipanche ramosa/potato, P. ramosa/tobacco, 
P. ramosa/tomato. However, a detailed study of the biological cycle of the $P$. ramosa/oilseed rape pathosystem has never been performed. Acquiring knowledge about the biology of the $P$. ramosa/oilseed rape pathosystem is all the more crucial as recent molecular biology works have proved that there exist at least two different $P$. ramosa pathovars with clearcut host specificities, which makes culture management in severely infested plots even more complicated.

In order to determine the adaptive traits that favour the parasite's success, we characterized the biological cycle of the $P$. ramosa/oilseed rape pathosystem. More precisely, we determined (1) the extent of the zone where oilseed rape root exudates stimulate $P$. ramosa seed germination; (2) the success rate of the first fixation steps of $P$. ramosa on host roots following its germination; (3) how the different phases of the $P$. ramosa development cycle tune in with the oilseed rape cycle; (4) the phenotypic and agronomical consequences of the parasitism of $P$. ramosa on oilseed rape. In order to make it easier to study the early development steps of $P$. ramosa, we decided to work with in vitro and sandwich co-cultivation methods. In parallel, a field trial was

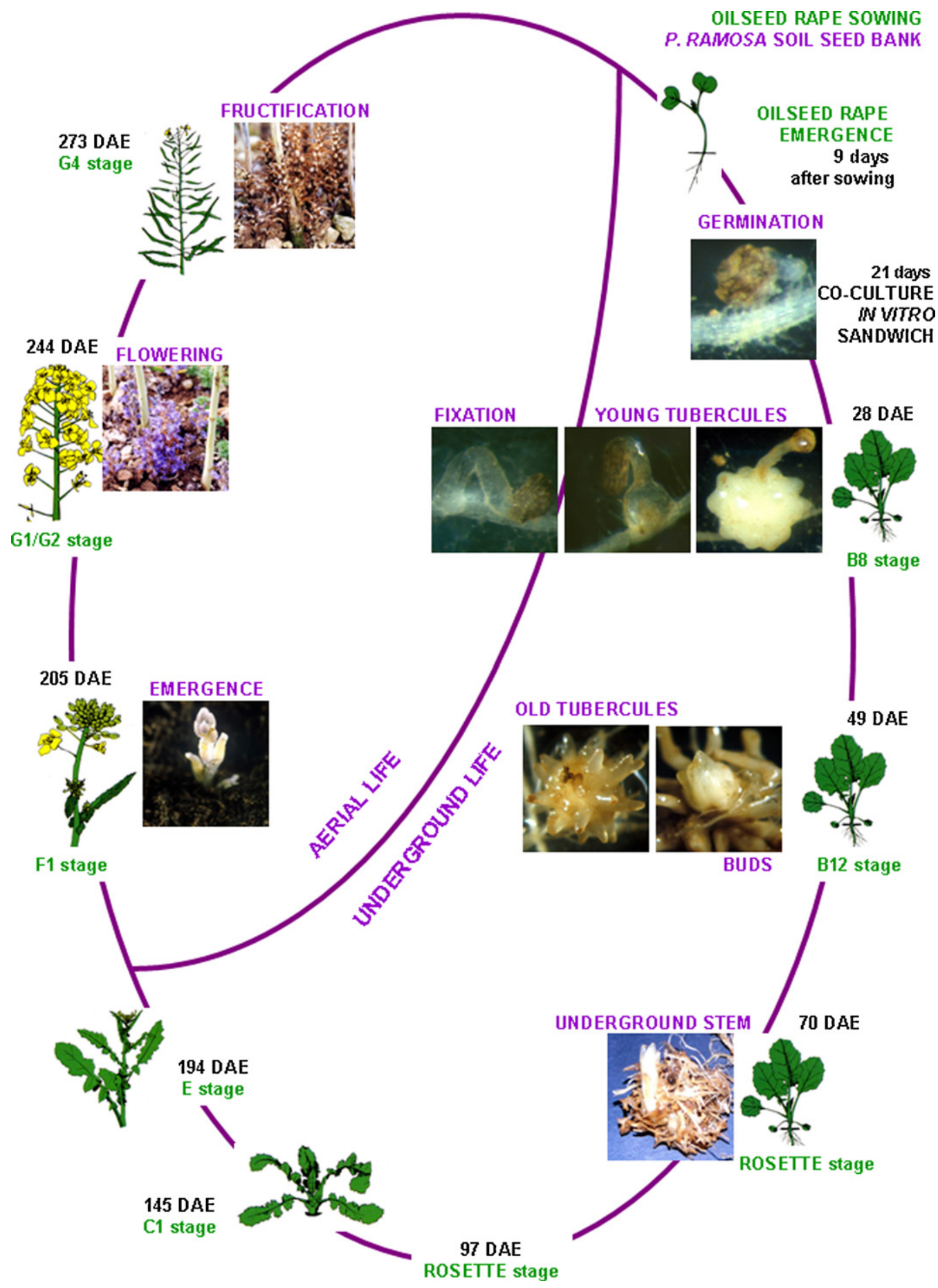

Fig. 1. Development cycle of the Phelipanche ramosa/oilseed rape pathosystem in Charente-Maritime (France). 
performed to characterize the consequences of $P$. ramosa parasitism on oilseed rape at the whole plant level and at the canopy level.

\section{Materials and methods}

Laboratory and field experiments were conducted between 2000 and 2004.

\section{Seed origin}

The seeds were collected in 1999 from natural populations of $P$. ramosa that had severely infested fields of oilseed rape (Brassica napus L. Brassicaceae) in Saint-Pierre-de-Juillers (Latitude 45,9333; Longitude -0.3667; Charente-Maritime, France). Once harvested, the seeds were sifted to clean them. Oilseed rape seeds (var. Zénith) were provided by the CETIOM (Centre technique des
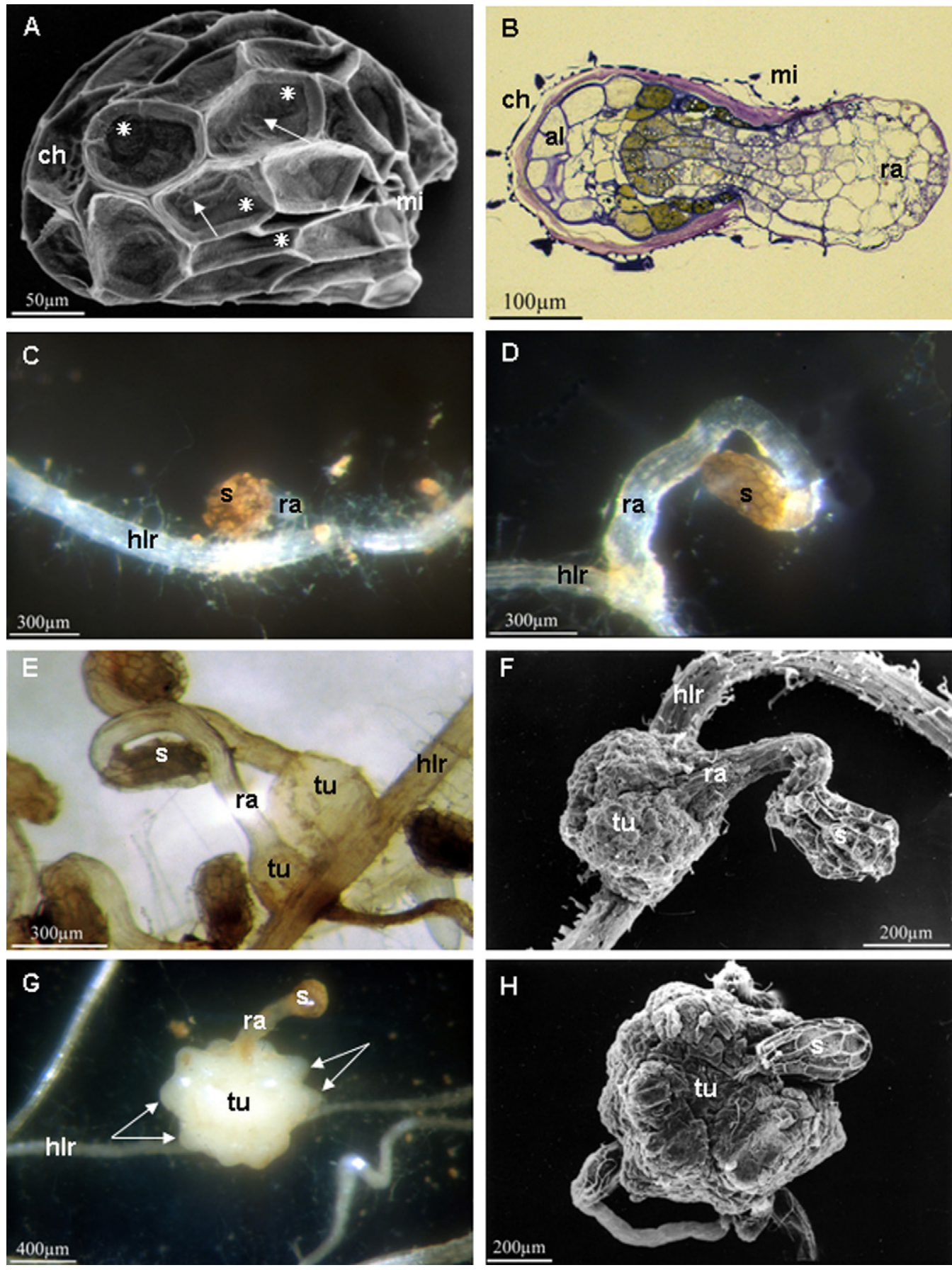

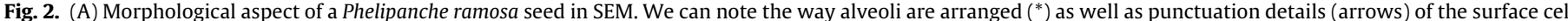

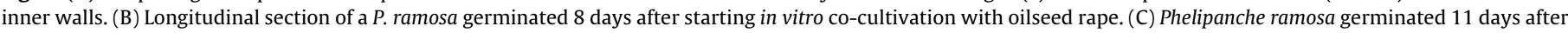

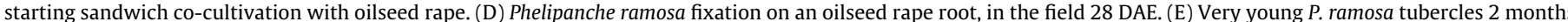

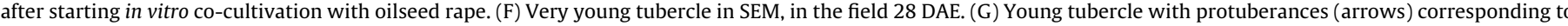

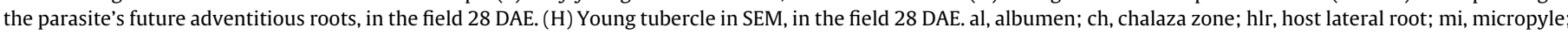
ra, radicle; s, seed; tu, tubercle. 
Table 1

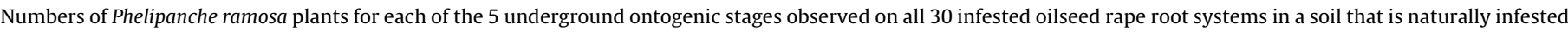
by broomrape in Charente-Maritime (France).

\begin{tabular}{|c|c|c|c|c|c|c|}
\hline \multirow[t]{2}{*}{ Sampling date (days after oilseed rape emergence (DAE)) } & \multicolumn{6}{|c|}{ Phelipanche ramosa ontogenic developmental stages } \\
\hline & Fixation & Young tubercle & Old tubercle & Bud & Underground stem & Total \\
\hline $7 \mathrm{DAE}$ & 0 & 0 & 0 & 0 & 0 & 0 \\
\hline $12 \mathrm{DAE}$ & 0 & 0 & 0 & 0 & 0 & 0 \\
\hline $19 \mathrm{DAE}$ & 0 & 0 & 0 & 0 & 0 & 0 \\
\hline $28 \mathrm{DAE}$ & 8 & 46 & 0 & 0 & 0 & 54 \\
\hline $49 \mathrm{DAE}$ & 1 & 60 & 36 & 12 & 0 & 109 \\
\hline $70 \mathrm{DAE}$ & 0 & 218 & 368 & 21 & 128 & 735 \\
\hline $97 \mathrm{DAE}$ & 0 & 0 & 100 & 20 & 90 & 210 \\
\hline $145 \mathrm{DAE}$ & 0 & 0 & 417 & 267 & 257 & 941 \\
\hline $194 \mathrm{DAE}$ & 0 & 0 & 0 & ++ & +++ & $>1500$ \\
\hline $244 \mathrm{DAE}$ & 0 & 0 & 0 & 0 & +++ & $>1500$ \\
\hline
\end{tabular}

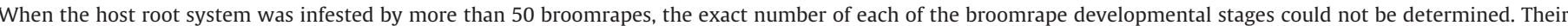
relative frequency is indicated by plus signs: +, low numbers of the parasite's developmental stage; ++, average numbers; +++, high numbers.

oléagineux métropolitains et du chanvre industriel, France). Phelipanche ramosa as well as oilseed rape seeds were kept in glass containers at room temperature.

\section{In vitro experiment}

After disinfection (70\% ethanol, 5 min, and 3\% calcium hypochlorite solution, $10 \mathrm{~min}$ ), $15-25$ seeds of $P$. ramosa were laid on Whatman GF/A paper discs (Ø $12 \mathrm{~mm}$ ). Eight discs prepared that way were placed on a Whatman GF/A paper sheet $(\varnothing 90 \mathrm{~mm}$ ) at the bottom of a Petri dish $(\varnothing 90 \mathrm{~mm})$, and then hydrated. Twenty Petri dishes, containing 120-200 seeds each, were placed in darkness at $20^{\circ} \mathrm{C}$ for 14 days to pre-condition the seeds (obligate hydration period). Thereafter, one disinfected oilseed rape seed was placed each in a rectangular plastic box containing MS $(1 / 2)$ (Murashige and Skoog, 1962) nutrient solution with 1\% agar. Twenty boxes prepared that way were placed in a growth chamber, at $23 \pm 1{ }^{\circ} \mathrm{C}$ (day) and $18 \pm 1{ }^{\circ} \mathrm{C}$ (night), with a 16 -h photoperiod, and $70 \mu \mathrm{mol} \mathrm{m}^{-2} \mathrm{~s}^{-1}$ photosynthetic photon flux density (PPFD). Once the oilseed rape root system had developed (i.e. 2 weeks after the beginning of the experiment), the 8 discs bearing the preconditioned $P$. ramosa seeds were transferred under the host root system. The $P$. ramosa/oilseed rape co-cultivation was carried out in the same temperature and light conditions. The development of the parasite on oilseed rape roots was monitored for 12 weeks. The observations were carried out under a stereo microscope daily for 4 weeks, and then once a week for the following 8 weeks. For each observation, the percentage of $P$. ramosa germination induced by oilseed rape root exudates was counted, and the early developmental stages of the parasite on its host were recorded. Our observations were also carried out in light and scanning electron microscopy (SEM). The whole experiment was performed twice.

\section{Sandwich experiment}

Losner-Goshen and collaborators' method (1998) was applied, with slight modifications. After disinfection (70\% ethanol, $5 \mathrm{~min}$, and 3\% calcium hypochlorite solution, $10 \mathrm{~min}$ ), $441 \mathrm{mg}-P$. ramosa seed samples (approximately 350 seeds each) were dried under a laminar flow at room temperature for $24 \mathrm{~h}$. Then each sample was sprinkled onto a GF/A sheet $(\varnothing 90 \mathrm{~mm})$ at the bottom of a Petri dish $(\varnothing 90 \mathrm{~mm})$, and then hydrated. The 44 Petri dishes were placed in darkness at $20^{\circ} \mathrm{C}$ for 14 days to achieve seed preconditioning. Forty-four oilseed rape seeds were laid individually onto GF/A sheets (Ø90 mm) at the bottom of Petri dishes $(\varnothing 90 \mathrm{~mm})$, and then hydrated. After oilseed rape seed germination in darkness at $30^{\circ} \mathrm{C}$, each oilseed rape seedling was laid onto a $\mathrm{GF} / \mathrm{A}$ sheet $(\varnothing 90 \mathrm{~mm})$ in contact with the pre-conditioned $P$. ramosa seeds. A second sheet was added to cover all the seeds. The sandwiched individual oilseed rape seedling and broomrape seeds were placed on pierced plastic Petri dishes (Ø $90 \mathrm{~mm}$ ) whose sides had been notched. Each of the 44 modified Petri dishes was placed slantwise inside a terra-cotta pot $(\varnothing 15 \mathrm{~cm})$ filled two-thirds full with a 1 vol:1 vol potting substrate and planting substrate soil mix. Twenty $\mathrm{ml}$ of MS (1/2) nutrient solution was added to each pot. The co-cultivation of the $P$. ramosa/oilseed rape pathosystem was carried out in the greenhouse $\left[23 \pm 1^{\circ} \mathrm{C}\right.$ (day) and $18 \pm 1^{\circ} \mathrm{C}$ (night), and $55 \%$ relative humidity]. The natural light was complemented by artificial light ( $100 \mu \mathrm{mol} \mathrm{m}^{-2} \mathrm{~s}^{-1}$ PPFD) to have a 16 -h photoperiod. Ten $\mathrm{ml}$ of nutrient solution was added daily. Phelipanche ramosa development on oilseed rape was assayed for 12 weeks. Samples were taken daily during the first week, every 2 days for the next 2 weeks and then once a week for the remaining 9 weeks. For each sampling, the root system of 2 oilseed rape plants was taken out and observed under a stereo microscope. The percentage of $P$. ramosa germination induced by oilseed rape root exudates was counted and the early developmental stages of the parasite on its host were recorded. Our observations were also carried out in light microscopy and SEM. The whole experiment was performed twice.

\section{Field trial}

On 28th August 2000, oilseed rape was sowed on a soil, consisting of silt, clay and sand, severely infested by $P$. ramosa and located in Villemorin (Latitude: 46.003887; Longitude: -0.296944, Charente-Maritime, France). The 4-replicate trial was carried out in whole Fischer blocks. The experiment was led through till oilseed rape harvest. Samples were taken at 10 different dates, i.e. 7, 12, 19, 28, 49, 70, 97, 145, 194 and 244 DAE (days after emergence). At each sampling date, 30 oilseed rape plants were dug out and observed under a stereo microscope. Oilseed rape developmental stages were determined and infested host roots were counted. Infestation intensity was estimated by counting the number of $P$. ramosa ontogenetic stages fixed on host roots as follows: (a) fixation; (b) young tubercle without adventitious roots; (c) old tubercle with adventitious roots; (d) bud with adventitious roots but without a stem; (e) underground stem; (f) stem emergence; (g) flowering; (h) fructification. Our observations were also carried out in light microscopy and SEM.

\section{Histological and cytological studies under a light microscope and a scanning electron microscope (SEM)}

The parasite on the host plant was taken at different development stages, fixed in a $4 \%$ glutaraldehyde solution in a $\mathrm{pH} 7.4$ cacodylate buffer for $24 \mathrm{~h}$ and then post-fixed in a $1 \%$ osmium 
tetroxide solution in the same buffer for $1 \mathrm{~h}$ (Ledbetter and Porter, 1963). After that, the samples were dehydrated by dipping them into ethanol baths of increasing ethanol concentrations and araldite-included according to Glauert and Glauert's method (1958). Then the included samples were sliced into semi-thin sections for photon microscopy and stained with toluidine blue.

For SEM observations, samples first fixed in a glutaraldehyde solution for several days were dehydrated by dipping them into baths of increasing ethanol concentrations. Then they were $\mathrm{CO}_{2}$-treated until the critical point and sputter-coated with gold (Guillaumin, 1980).

\section{Results}

Fig. 1 gives a comprehensive overview of all results detailed in the following and illustrates the developmental cycle of the parasite and its host.

\section{Underground life stage of Phelipanche ramosa}

Phelipanche ramosa seeds are oval-shaped, $350 \mu \mathrm{m}$ long, $250 \mu \mathrm{m}$ wide, and weigh $3 \mu \mathrm{g}$. They are covered by a hard reticulate coat. The narrowest end corresponds to the micropyle while the roundest opposite end corresponds to the chalaza (Fig. 2A). The testa contains alveolar cavities in it (Fig. 2A, ${ }^{*}$ ) which are composed of dehydrated cells aligned along the long axis of the seed. As the cytoplasmic content of cells is gone, the outer wall has collapsed and follows the circular punctuations of the inner wall (Fig. 2A, arrows). The albumen (Fig. 2B) is composed of 3 or 4 layers of cells containing numerous lipid globules and starch granules. It surrounds the primitive embryo devoid of radicle, gemmule or cotyledons. After pre-conditioning, only the $P$. ramosa seeds situated nearby the oilseed rape roots (less than $4 \mathrm{~mm}$ in our conditions) were able to germinate. The radicle of $P$. ramosa juts out of the micropyle region (Fig. 2B) and grows towards the host root (Fig. 2C). In the absence of fixation on oilseed rape roots, $P$. ramosa seeds degenerated and died in less than 3 or 4 days. In the in vitro method, $P$. ramosa seed germination occurred 3 days (61 growing day-degrees, base 0 ) after starting the co-cultivation. On the 8 th day, $P$. ramosa germination percentage was 50\% and it reached $95 \% 3$ days later. With the sandwich method, the lag-time was longer ( 7 days), the germination percentage was $50 \%$ on the 11 th day and it reached $90 \%$ on the 15th day. Taking into account the different lag-times probably due to the age of the oilseed rape seedlings when parasite and host were put together, we can consider that $P$. ramosa germination occurred when oilseed rape seedlings were 11-14 days old, while the maximal germination percentage was reached when they were 21 days old (Fig. 1 ).

In the field, oilseed rape emergence occurred 9 days after sowing (Fig. 1). When the first samples were taken 7, 12 and 19 DAE, host roots were not yet infected by $P$. ramosa (Table 1 ). Yet, the results obtained with the in vitro and sandwich methods indicate that the maximal germination percentage for $P$. ramosa seeds is reached when oilseed rape is 21 days old. We can therefore hypothesize that the 21-day-old-oilseed rape root exudates (B6, i.e. 6-leaf stage) did induce the germination of numerous $P$. ramosa seeds, but these germinations were very likely lost due to the uprooting and washing steps of the root systems. Parasite fixations and young tubercles were observed from the 4 th sampling date onward (Fig. 1, B8, i.e. 8-leaf stage, $28 \mathrm{DAE}$ ). It is important to note that $P$. ramosa only fixed itself on the lateral roots of oilseed rape. At that time, young tubercles were already 5 times as numerous as fixations (Table 1). Field results were in accordance with those obtained with the in vitro and sandwich methods. Phelipanche ramosa fixations were detected when oilseed rape was 30 days old and young tubercles only developed 1 month later. In these controlled conditions, $P$. ramosa development did not go further than the young-tubercle stage throughout the 3-month long experiment (Fig. 2 D-H).

When $P$. ramosa first penetrated into oilseed rape roots, meristematic cell proliferation allowed the haustorium, which at that stage was not yet functional, to make its way through the host tissues (Fig. 3A). Later on, only apical cells remained able to proliferate whereas distal cells got organized into a parenchyma and xylem elements differentiated. Once haustorial apical cells had made contact with the host's vascular system cells, they stopped dividing and migrating into the host. They stuck to the host vessel cells without perforating them. The continuity between broomrape haustorium vessels and the host xylem is clearly visible (Fig. 3B).

Old tubercles and buds were observed when oilseed rape was 49 days old or older (Fig. 1, B12, i.e. 12-leaf stage). The proliferation of cells located around the caulinary meristem, at the origin of the floral scape, led to the formation of a wreath of adventitious roots (Fig. 4A, arrows) which in some cases were able to make contact with other host roots and produced secondary haustoria. Once adventitious roots were formed, the tubercle rapidly turned into a bud thanks to its apical cells. Inside the bud, the caulinary meristem was protected by scales (Fig. 4B). It is important to note that at 49 DAE only one new fixation was detected, while young and old tubercles were much more numerous than buds (Table 1). From that point onward the buds grew vertically and formed young underground stems which made their way through the soil towards the surface. The first underground stems (Fig. 4C) were observed 70 DAE (Fig. 1, rosette stage). At that time fixations had all disappeared whereas all other stages except the bud stage were in constantly increasing numbers (Table 1). At the following sampling date (97 DAE, rosette stage), young tubercles had disappeared. Till $145 \mathrm{DAE}$ (C1, i.e. bolting stage), the numbers of old tubercles, buds and underground stems increased considerably. Conversely, no new fixation or young tubercle was detected. During that period, oilseed rape stopped its vegetative development, and no new $P$. ramosa seed germination leading to the development of new young parasitic developmental stages appeared to have been induced. At 194 DAE (E-stage, i.e. separate-flower-bud stage), old tubercles were not visible any more while each root system carried more than 50 buds and underground stems (Table 1 ).

\section{Aerial phase of $P$. ramosa}

Phelipanche ramosa emerged at the soil surface 205 days after oilseed rape emergence (Fig. 1, F1, i.e. early flowering stage). The short, frail, rather hairy, branched stem bulged out at its base (Fig. 4D). It had leaves that contained no chlorophyll pigments and were reduced to 6 - to $12 \mathrm{~mm}$ long thick, acuminate, alternate scales. This non-chlorophyllic, scaly axis then turned into a floral scape 244 DAE (G1/G2, i.e. early fructification stage). The flowers were $1-1.5 \mathrm{~cm}$ long. They were inserted individually at the axils of scaly bracts. They had an irregular, curved shape, and a bluetinted mauve colour. They did not have distinct peduncles and they were grouped in rather long floral scapes when flowering was well advanced (Fig. 5A and B). It is important to note that at that last time-point buds could no longer be found while large numbers of underground stems with surrounding bunches of adventitious roots remained ready to emerge (Table 1 ). Once fecundation had taken place, each pollinated flower turned into a capsule containing approximately 600-800 seeds each (Fig. 5C). Phelipanche ramosa started fructifying 273 DAE (Fig. 1, G4, i.e. end-of-fructification stage) and the floral scapes of broomrape were ripe a few days after those of oilseed rape (Fig. 5D). 

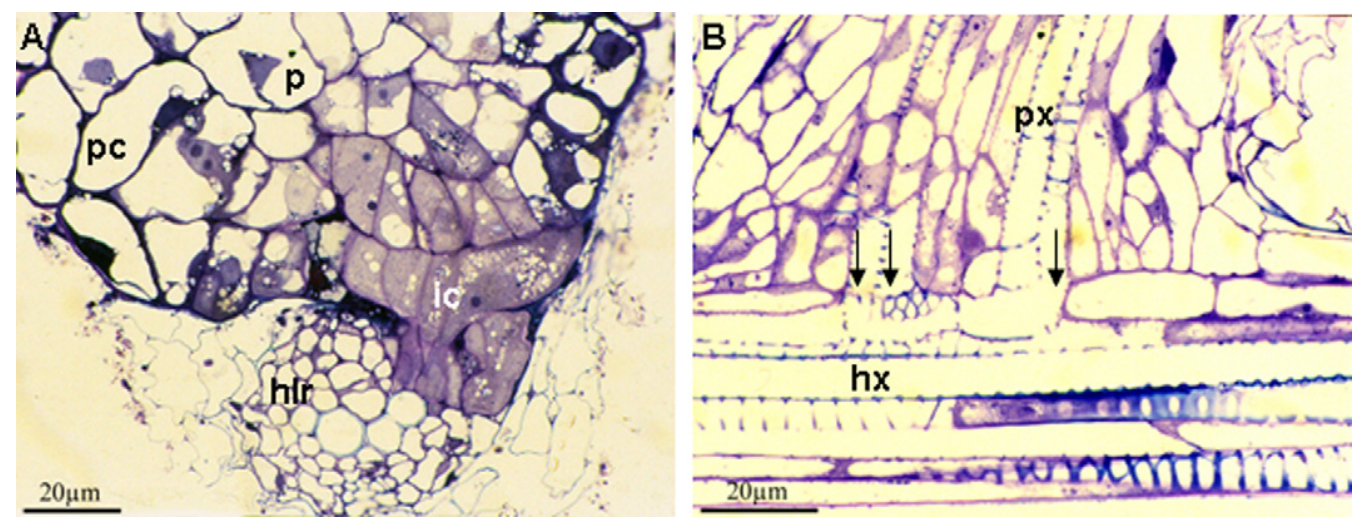

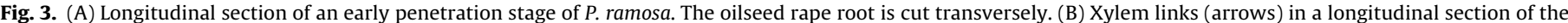
base of a P. ramosa tubercle. hlr, host lateral root; hx, host's xylem; ic, intrusive cells; p, parasite; pc, parenchyma cells; px, parasite's xylem.
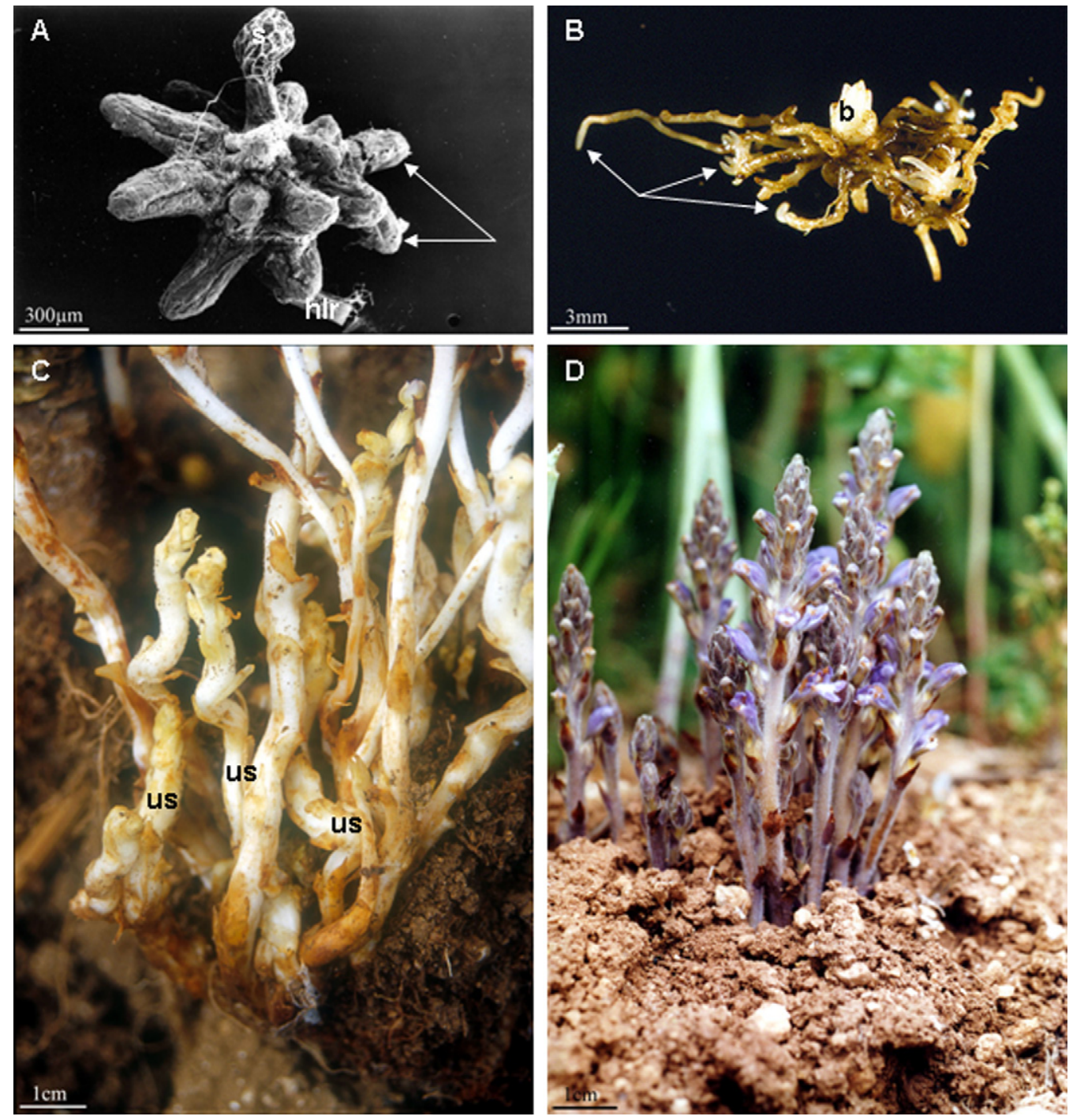

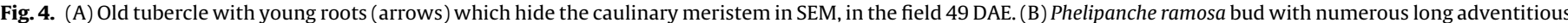

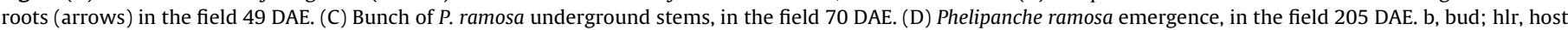
lateral root; us, underground stem.

\section{Phenotypic and agronomical consequences on oilseed rape}

During the autumn-winter phase of oilseed rape, the shoot part of the host plant showed no visible parasitism-related symptoms. It was only by digging out root systems and examining them closely that we detected the presence of $P$. ramosa. But in the spring phase, the first symptoms became visible when oilseed rape floral peduncles started growing (Fig. 1, E stage). Parasitic attack induced oilseed rape dwarfism, which was visible as a depressive zone at the field level (Fig. 6A, arrows) and leaf chlorosis (Fig. 6B, arrows). Once $P$. 

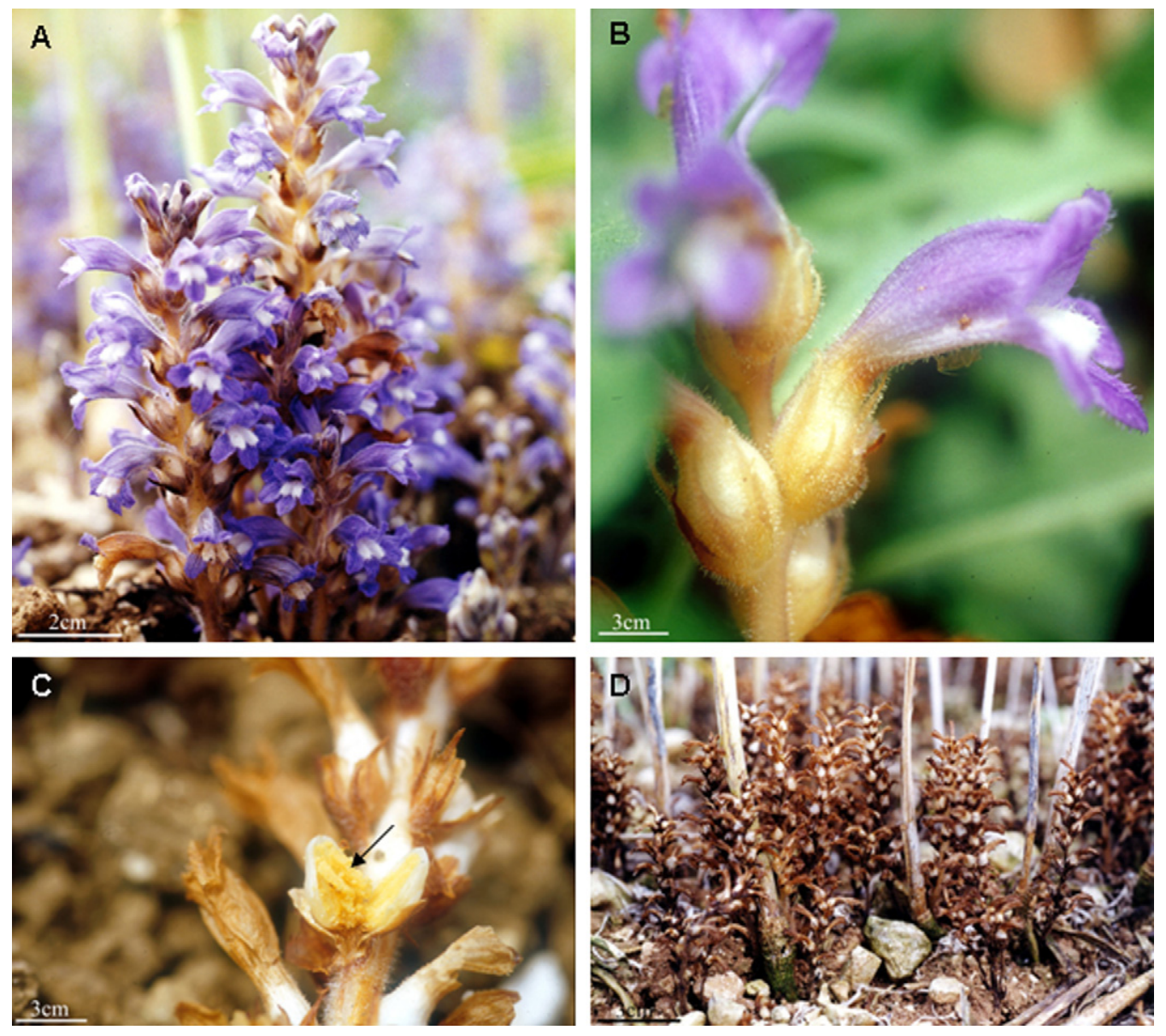

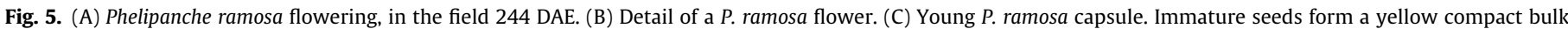
(arrow). (D) Fructified P. ramosa, in the field 273 DAE.

ramosa had emerged, its branched floral scapes were easily identifiable. The most severely infested parts were usually those on the outskirts of the fields (Fig. 6C). In the case of severe infestations, each oilseed rape plant could harbour as many as 15-20 floral scapes; the infested zone appeared then to be fully covered by $P$. ramosa (Fig. 6D). When oilseed rape ripened, the size of the depressive zone increased while the low density of the crop made it possible for weeds to develop. Infested oilseed rapes produced few siliques and many of them aborted (Fig. 6E, arrows). Yield losses were significant: from an average $38 \mathrm{q} \mathrm{ha}^{-1}$ when oilseed rape was healthy, they went down to $4 \mathrm{q} \mathrm{ha}^{-1}$ in the most severely infested fields. After oilseed rape harvest, only wilted $P$. ramosa floral scapes remained (Fig. 6F), perfectly aligned with the sowing lines.

\section{Discussion}

A combination of field and controlled experimental approaches allowed us to characterize precisely the different steps of the $P$. ramosa cycle, at the cell level as well as at the whole plant level. To our knowledge, this is the first such study to be carried out about this pathosystem.

\section{Biological traits of $P$. ramosa contributing to the success of its biological cycle}

Phelipanche ramosa as a parasite of oilseed rape possesses different specific traits that contribute to the success of its cycle. The first trait concerns its dispersion: it produces light, minute seeds in huge numbers. Thus its seeds are easily dispersed by wind, waters, animals, farming machinery, and contaminated seed transport (Berner et al., 1994; Parker and Riches, 1993). The second trait is the toughness of its seed coat. This trait is common to Orobanche and Striga seeds and could explain why their seeds can retain their germinating capacity in the soil for several years (Parker and Riches, 1993; Worsham, 1987). The third trait lies in the need for seed germination to be stimulated by host root exudates. We observed that $P$. ramosa seed germination could only occur within a short distance from oilseed rape roots. We found that distance to be $4 \mathrm{~mm}$. Oilseed rape root exudates thus appear to have a stimulating effect within a limited zone around the roots compared to the $10 \mathrm{~mm}$ with the faba bean/O. crenata pathosystem (Sallé et al., 1984). Such a system could prevent the seeds from germinating in the absence of a host and avoid $P$. ramosa seed germination at too great a distance from oilseed rape roots.

The three biological traits of $P$. ramosa as a parasite of oilseed rape mentioned above complete other traits already mentioned in the literature, namely: the absence of a primary dormancy, or a very early break of primary dormancy, as $P$. ramosa seeds can germinate as early as harvest time. Apart from the indispensable presence of a susceptible host plant, $P$. ramosa seed pre-conditioning and germination do not require any specific environmental conditions (Gibot-Leclerc et al., 2004, 2006).

\section{Early efficacy of root exudates on P. ramosa germination}

Our results show that whichever co-cultivation technique was used, $P$. ramosa seed germination was massively induced $21 \mathrm{DAE}$, while oilseed rape had only reached the 6-leaf stage. Oilseed rape 

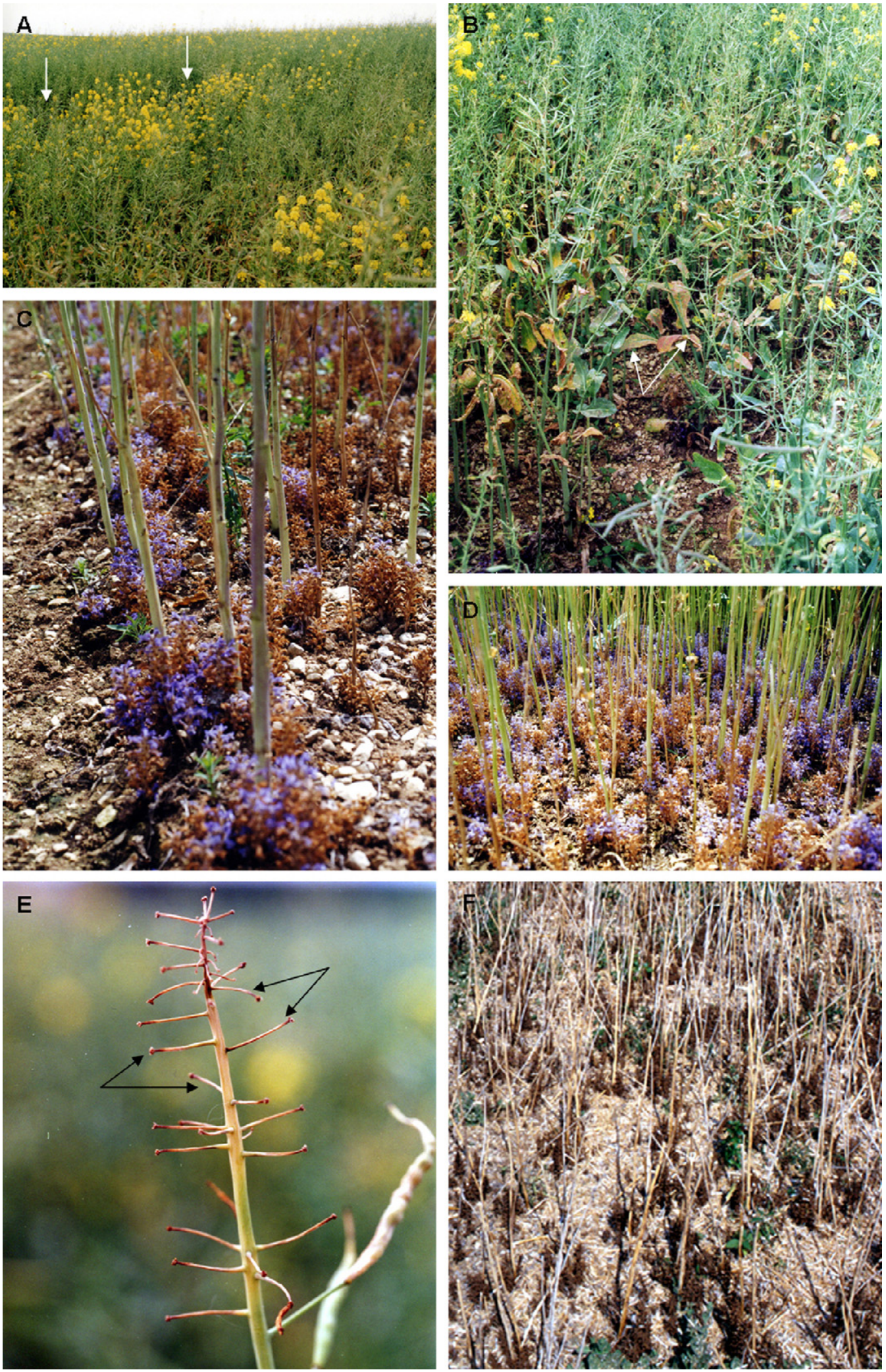

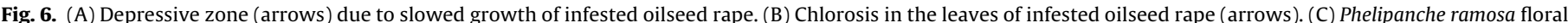

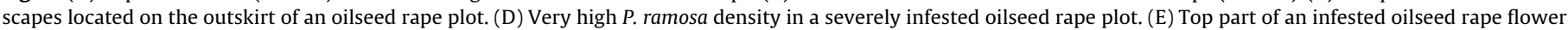
bunch with aborted siliques (arrows). (F) Harvested infested oilseed rape plot

root exudates therefore appear to be effective in the early stages of its growth. For P. ramosa, such earliness has been shown with tobacco (Labrada, 1994). It is noteworthy that no new fixation or young tubercle was observed while oilseed rape was between the rosette stage (97 DAE) and the shooting stage (145 DAE). Taken together, these results suggest a tight correlation between the developmental stage reached by the host and the efficacy of its root exudates. 


\section{Fixation, a fundamental process for resource acquisition by $P$.} ramosa

Once it has germinated, $P$. ramosa very quickly fixes itself (28 days) on oilseed rape host roots. A similar precocity was previously reported on hemp and tobacco roots (Brault et al., 2007; Labrada, 1994). Broomrape fixation has to be completed for the parasite to be able to penetrate host tissues later and draw the carbon, mineral and water resources needed for its growth. A continuum between oilseed rape and $P$. ramosa xylems was highlighted. Such xylem-to-xylem contacts have also been evidenced in the case of the $P$. ramosa/carrot pathosystem (Zehhar et al., 2003). Our lightmicroscopy observations did not allow us to determine whether host and parasite xylem vessels were simply adjacent or had made direct lumen contact (Hibberd and Jeschke, 2001).

Xylem-mediated solute supply to the parasite is likely to be low due to the low transpiration rate of the parasite that generates only a weak driving force for the solute flux within the xylem (Hibberd et al., 1999). Yet we did not observe any phloem-to-phloem connexions. But phloem tissues are found in broomrape haustoria (Dörr and Kollmann, 1975; Hibberd and Jeschke, 2001). The host phloem is known to provide almost all sugars ( $>99 \%$ ) and most minerals such as nitrogen, magnesium and potassium (Abbes et al., 2009; Hibberd and Jeschke, 2001; Hibberd et al., 1999).

\section{Tuning of the host and parasite development cycles}

Phelipanche ramosa tightly tunes the duration of its biological cycle to its host's (273 days). Such tuning was found for $P$. ramosa parasiting different species (Brault et al., 2007; Kogan, 1994; Neumann and Sallé, 2000), with a biological cycle that can last 45-150 days according to the species considered. In our study, $P$. ramosa emerged, i.e. started the aerial phase of its cycle, when oilseed rape started flowering, in accordance with common observations on different host plants, such as hemp, eggplant, tobacco, tomato or water melon (Brault et al., 2007; Kogan, 1994; Labrada, 1994). Another aspect of cycle tuning was when $P$. ramosa floral scapes started growing at the same time as oilseed rape started forming its siliques. Such tuning is believed to enable $P$. ramosa to deprive the host of nutrients as optimally as possible by diverting water and nutrients from the host for its own use.

\section{Consequences of nutrient diversion on the growth and agronomical performances of oilseed rape}

The broomrape biological cycle phase that occurs between seed germination and haustorium penetration takes place exclusively underground, so it cannot be detected by outsiders. Besides, the symptoms of $P$. ramosa parasitism on oilseed rape become detectable late in the oilseed rape life cycle, i.e. only once its floral peduncles start elongating. An overall slower growth of oilseed rape could be observed, along with leaf chlorosis, low silique production, and numerous abortions. Such symptoms are often seen in host/parasite relationships (Sallé et al., 1995).

By developing on host roots, the parasite competes with the host for water, minerals and sugars. Sometimes, the decrease in host biomass is not fully compensated for by parasite biomass (Grenz et al., 2008). In this case, photosynthetic protein diversion is likely to prevent the host from maintaining its photosynthetic level. This phenomenon could be at the origin of the oilseed rape leaf chlorosis and biomass drop observed in our study. Besides, following the source-sink concept, Manschadi et al. (2001) proposed that the parasite could be a priority sink compared to host vegetative organs and newly formed pods, whereas pods in the filling stage could be priority sinks compared to the parasite. This could account for the low numbers of siliques and the numerous abortions observed in our study. The high yield losses of oilseed rape that we observed are in accordance with other studies (Bernhard et al., 1998; Manschadi et al., 2001; Mesa-García and García-Torres, 1986).

Last of all, hormonal imbalance, characterized by a decrease in gibberellin and cytokinine content and an increase in abscisic acid content, could cause the growth delay at the origin of the infested plants' dwarfism. The imbalance could also result from wounds and water stress caused by the parasite's setting in (Watling and Press, 1997).

\section{Conclusion}

The highly specialized parasitic way of life set up by Phelipanche ramosa on oilseed rape highlights different adaptive traits that favour its success. These traits concern $P$. ramosa germination and fixation, with the determination of a 4-mm influence zone of oilseed rape root exudates on parasitic seed germination and an early effect of exudates followed by a very rapid fixation of the parasite on host roots. Consequently, an ever-increasing parasitic seed bank is maintained. These traits are more globally related to the whole biological cycle of $P$. ramosa since the different steps of its cycle depend little on weather conditions but completely on the presence of a host. Our study evidenced a fine tuning between oilseed rape and $P$. ramosa cycle phases, which led to a synchronization of their fructification stages. Although the way P. ramosa germinates and fixes itself on host roots is well characterized, the physiological responses that induce the fine tuning of the parasite's cycle phases to its host's remain to be elucidated. Besides, the fulfilment of $P$. ramosa's biological cycle induces consequences on oilseed rape, at the phenotypic and the agronomical levels.

Our study can constitute a relevant basis for future experimental studies. Knowing the number of days needed for $P$. ramosa to reach its early developmental stages, which take place underground and are thus invisible to outsiders, will make it possible to better plan oilseed rape root sampling in order to get $P$. ramosa plants at the wanted stage. Concerning $P$. ramosa emergence, it will be possible to plan observations from oilseed rape phenology once it has reached the early flowering stage. As for the parasite's later developmental stages, they are visible to the naked eye, which solves the problem. In addition to these practical applications, our work opens onto new research perspectives that can focus on key-processes of the host-parasite relationship. In particular, the trophic relationships concerning carbon assimilates and minerals such as nitrogen need to be further investigated in order to better understand the competition that takes place between host and parasite in this pathosystem.

\section{Acknowledgements}

The present work was financed jointly by the CETIOM and the Poitou-Charentes region. We thank the CETIOM (experimental station of Surgères, France) for technical support at harvest time.

\section{References}

Abbes, Z., Kharrat, M., Delavault, P., Chaïbi, W., Simier, P., 2009. Nitrogen and carbon relationships between the parasitic weed Orobanche foetida and susceptible and tolerant faba bean lines. Plant Physiol. Biochem. 47, 153-159.

Berner, D.K., Cardwell, K.F., Faturoti, B.O., Ikie, F.O., Williams, O.A., 1994. Relative roles of wind, crop seeds, and cattle in dispersal of Striga spp. Plant Dis. 78 402-406.

Bernhard, R.H., Jensen, J.E., Andreasen, C., 1998. Prediction of yield loss caused by Orobanche spp. in carrot and pea crops based on soil seedbank. Weed Res. 38, 191-197.

Boulet, C., Pineault, D., Benharrat, H., Simier, P., Delavault, P. 2007. Adventices du colza et orobanche rameuse. In: AFPP-Vingtième conférence du COLUMA: Journée internationale sur la lutte contre les mauvaises herbes, Fontenay-LeCompte, France, pp. 326-345. 
Bouwmeester, H.J., Matusova, R., Zhongkui, S., Beale, M.H., 2003. Secondary metabolite signalling in host-parasitic plant interactions. Curr. Opin. Plant Biol. 6, 358-364.

Brault, M., Betsou, F., Jeune, B., Tuquet, C., Sallé, G., 2007. Variability of Orobanche ramosa populations in France as revealed by cross infestations and molecular markers. Environ. Exp. Bot. 67, 271-280.

Buschmann, H., Gonsior, G., Sauerborn, J., 2005. Pathogenecity of branched broomrape (Orobanche ramosa) populations on tobacco cultivars. Plant Pathol. 54, 650-656.

Dörr, I., Kollmann, R., 1975. Strukturelle Grundlagen des Parasitismus bei Orobanche. II. Die Differenzierung der Assimilat-Leitungsbahn im Haustorialgewebe. Protoplasma 83, 185-199.

Echevarría-Zomeño, S., Pérez de Luque, A., Jorrín, J., Maldonado, A.M., 2006 Pre-haustorial resistance to broomrape (Orobanche cumana) in sunflower (Helianthus annuus): cytochemical studies. J. Exp. Bot. 57, 4189-4200.

Gibot-Leclerc, S., Brault, M., Pinochet, X., Sallé, G., 2003. Potential role of winter rape weeds in the extension of broomrape in Poitou-Charentes. C. R. Biol. 326, 645-658.

Gibot-Leclerc, S., Corbineau, F., Sallé, G., Côme, D., 2004. Responsiveness of Orobanche ramosa L. seeds to GR 24 as related to temperature, oxygen availability and water potential during preconditioning and subsequent germination. Plant Growth Regul. 43, 63-71.

Gibot-Leclerc, S., Pinochet, X., Sallé, G., 2006. Orobanche rameuse (Orobanche ramosa L.) du colza: un risque émergent sous surveillance. Oléagineux Corps Gras Lipides $13,200-205$.

Gibot-Leclerc, S., Charles, J., Dessaint, F., 2009. Potential host plant susceptibility to two Orobanche ramosa L. races. In: XIIIe Colloque International sur la Biologie des Mauvaises Herbes, Dijon, France, pp. 446-456.

Glauert, A.M., Glauert, R.H., 1958. Araldite as an embedding medium for electron microscopy. J. Biophys. Biochem. Cytol. 4, 191-195.

Goldwasser, Y., et al., 2001. Control of Orobanche aegyptiaca and Orobanche ramosa in potato. Crop Prot. 20, 403-410.

Grenz, J.H., Iștoc, V.A., Manschadi, A.M., Sauerborn, J., 2008. Interactions of sunflower (Helianthus annuus) and sunflower broomrape (Orobanche cumana) as affected by sowing date, resource supply and infestation level. Field Crops Res. $107,170-179$.

Guillaumin, D., 1980. La pratique du microscope électronique à balayage en biologie. Edition Masson, Paris.

Haidar, M.A., Bibi, W., Sidahmed, M.M., 2003. Response of branched broomrape (Orobanche ramosa) growth and development to various soil amendments in potato. Crop Prot. 22, 291-294.

Hibberd, J.M., Jeschke, W.D., 2001. Solute flux into parasitic plants. J. Exp. Bot. 52 2043-2049.

Hibberd, J.M., Quick, W.P., Press, M.C., Scholes, J.D., Jeschke, W.D., 1999. Solute fluxes from tobacco to the parasitic angiosperm Orobanche cernua and the influence of infection on host carbon and nitrogen relations. Plant Cell Environ. 22, 937-947.

Joel, D.M., 2009. The new nomenclature of Orobanche and Phelipanche. Weed Res. $49,1-6$.

Joel, D.M., Hershenhorn, Y., Eizenberg, H., 2007. Biology and management of weedy root parasites. Hort. Rev. (Am. Soc. Hortic. Sci.) 38, 267-349.

Keyes, W.J., Taylor, J.V., Apkarian, R.P., Lynn, D.G., 2001. Dancing together. Social controls in parasitic plant development. Plant Physiol. 127, 1508-1512.

Kogan, M., 1994. Orobanche in Chile: a research report. In: Pieterse, A.H., Verkleij, J.A.C., ter Borg, S.J. (Eds.), Biology and Management of Orobanche. Proc. 3rd Int. Workshop on Orobanche and related Striga Res., Roy. Trop. Inst. Amsterdam, pp. 599-603.

Labrada, R., 1994. Occurrence and control of Orobanche ramosa L. in Cuba. In: Pieterse, A.H., Verkleij, J.A.C., ter Borg, S.J. (Eds.), Biology and Management of Orobanche.
Proc. 3rd Int. Workshop on Orobanche and related Striga Res., Roy. Trop. Inst. Amsterdam, pp. 604-610.

Ledbetter, M.C., Porter, K.R., 1963. A “microtubule" in plant cell fine structure. J. Cell Biol. 19, 239-250.

Losner-Goshen, D., Portnoy, V.H., Mayer, A.M., Joel, D.M., 1998. Pectolytic activity by the haustorium of the parasitic plant Orobanche L. (Orobanchaceae) in host roots. Ann. Bot. 81, 319-326.

Lu, Y.H., Melero-Vara, J.M., García-Tejada, J.A., Blanchard, P., 2000. Development of SCAR markers linked to the gene Or5 conferring resistance to broomrape (Orobanche cumana Wallr.) in sunflower. Theor. Appl. Genet. 100, 625-632.

Manschadi, A.M., Sauerborn, J., Stützel, H., 2001. Quantitative aspects of Orobanche crenata infestation in faba beans as affected by abiotic factors and parasite soil seed bank. Weed Res. 41, 311-324.

Mesa-García, J., García-Torres, I., 1986. Effect of planting date on parasitism of broadbean (Vicia faba) by crenate broomrape (Orobanche crenata). Weed Sci. 34, 544-550.

Murashige, T., Skoog, F., 1962. A revised medium for rapid growth and bio assays with tobacco tissue cultures. Physiol. Plant 15, 473-497.

Musselman, L.J., 1980. The biology of Striga, Orobanche and other root-parastitic weeds. Annu. Rev. Phytopathol. 18, 463-489.

Neumann, U., Sallé, G., 2000. Defence mechanisms of plants against parasitic angiosperms. C. R. Acad. Agric. France 86, 85-96.

Parker, C., Riches, C.R., 1993. Parasitic Weeds of the World: Biology and Control. CAB International, Wallingford.

Pérez de Luque, A., Siliero, J.C., Moral, A., Cubero, J.I., Rubiales, D., 2004. Effect of sowing date and host resistance on the establishment and development of Orobanche crenata in faba bean and common vetch. Weed Res. 44, 282-288.

Press, M.C., Graves, J.D., 1995. Parasitic Plants. Chapman and Hall, London.

Press, M.C., Phoenix, G.K., 2005. Impacts of parasitic plants on natural communities. New Phytol. 166, 737-751.

Rubiales, D., 2003. Parasitic plants, wild relatives and the nature of resistance. New Phytol. 160, 459-461.

Sallé, G., Aber, M., Le Coz, S., 1984. Comparative histo-physiological study of the germination and establishment of three major parasites: Viscum, Orobanche and Cuscuta. In: Parker, C., Musselman, L.J., Polhill, R.M., Wilson, A.K. (Eds.), 3rd Int. Symp. on Parasitic Weeds. ICARDA/International Parasitic Seed Plant Research Group. Aleppo, Syria, pp. 10-21.

Sallé, G., Raynal-Roques, A., Tuquet, C., 1995. Un fléau en Afrique, les Striga. La Vie Sci. 12, 27-46.

Sallé, G., Tuquet, C., Neumann, U., 2000. Parasitic angiosperms: biology and methods of control. C. R. Acad. Agric. France 86, 59-67.

Sauerborn, J., 1991. Parasitic Flowering Plants, Ecology and Management. Verlag Josef Margraf, Weickersheim.

Schneeweiss, G.M., 2007. Correlated evolution of life history and host range in the non photosynthetic parasitic flowering plants Orobanche and Phelipanche (Orobanchaceae). J. Evol. Biol. 20, 471-478.

Watling, J.R., Press, M.C., 1997. How is the relationship between the $C_{4}$ cereal Sorghum bicolour and the $\mathrm{C}_{3}$ root-hemiparasites Striga hermonthica and Striga asiatica affected by elevated $\mathrm{CO}_{2}$ ? Plant Cell Environ. 20, 1292-1300.

Worsham, A.D., 1987. Germination of witchweed seeds. In: Musselman, L.J. (Ed.), Parasitic Weeds in Agriculture, vol. 1. CRC Press, Boca Raton, pp. 45-61.

Yoder, J.I., 2001. Host-plant recognition by parasitic Scrophulariaceae. Curr. Opin. Plant. Biol. 4, 359-365.

Zehhar, N., Labrousse, P., Arnaud, M.C., Boulet, C., Bouya, D., Fer, A., 2003. Study of resistance to Orobanche ramosa in host (oilseed rape and carrot) and non-host (maize) plants. Eur. J. Plant Pathol. 109, 75-82. 